ISSN 0206-5657. Вісник Львівського університету. Серія біологічна. 2019 Випуск 81. С. 50-56 Visnyk of the Lviv University. Series Biology. 2019. Issue 81. P. 50-56

УДК 579.873.1:577.181.4 https://doi.org/10.30970/vbi.2019.81.06

\title{
TN5-BASED TRANSPOSON MUTAGENESIS OF STREPTOMYCES GHANAENSIS ATCC14672: SEARCHING FOR NOVEL REGULATORS OF MOENOMYCIN PRODUCTION
}

\author{
Y. Kuzhyk ${ }^{1}$, Y. Rebets ${ }^{2}$, I. Popkoํㅜ I. Ostash ${ }^{1}$, S. Walker ${ }^{2}$, V. Fedorenko ${ }^{1}$, B. Ostash ${ }^{1, *}$ \\ ${ }^{1}$ Ivan Franko National University of Lviv \\ 4, Hrushevskyi St., Lviv 79005, Ukraine \\ ${ }^{2}$ Harvard Medical School \\ 4, Blackfan Circle, Boston, MA 02115, USA \\ *e-mail: bohdan.ostash@lnu.edu.ua
}

\begin{abstract}
Streptomyces ghanaensis ATCC14672 is the only genetically characterized natural producer of moenomycin $\mathrm{A}(\mathrm{MmA})$, a unique phosphoglycolipid antibiotic capable of direct inhibition of peptidoglycan glycosyltransferases. At the moment there are no drugs on the market that would target this step of peptidoglycan formation. There is much interest in development of MmA-based drugs to combat growing threat of multidrug resistant Grampositive infections. Consequently, there is also major interest in development of microbiological approaches towards production of this natural compound via submerged cultivation. Currently available ATCC14672 strains accumulate minute quantities of MmA, which fueled the investigations of genetic control of its biosynthesis over the last decade. Much of our understanding of the regulation of MmA production stems from homology-based approaches. Namely, homologs of known pleiotropic regulators of antibiotic production were searched in ATCC14672 genome and functionally characterized. Although this approach was largely successful, it left out of the focus those regulators of MmA production that share no similarity to the regulators identified in model streptomycetes. In this work we report an attempt to discover novel genes involved in regulation of moenomycin biosynthesis via the use of Streptomyces codon-adapted transposon Tn5, which represents an unbiased way to find genuinely new regualtors. After a primary screening of transposon library we were able to identify five Tn mutants that differed in morphology and/or total antibiotic production. We identified Tn5 insertion sites in these mutants through sequencing and re-analyzed their moenomycin production levels, revealing two strains with increased total antibiotic activity. The genes affected in Tn5 mutants were cloned into expression vectors and introduced back into wild type (ATCC14672) in order to study the effects of their increased dosage on the strain. One of the genes, ssfg_04565, exerted negative effects on antibiotic activity when introduced on the plasmid. Possible functions of the identified genes in the context of secondary metabolism are discussed.
\end{abstract}

Keywords: Streptomyces ghanaensis, Tn5, transposon mutagenesis, regulatory genes

Moenomycin A (MmA) is a founding member of a small family of phosphoglycolipid natural products that exert very specific and potent antibiotic action on Gram-positive cocci [8]. Particularly, by mimicking Lipid II, natural substrate for peptidoglycan glycosyltransferases, MmA tightly and irreversibly binds the latter thus blocking elongation of peptidoglycan chains and causing bacterial cell rupture [1]. Uniqueness of MmA structure and mode of action makes it an ideal target for development as a drug of novel class. Such antibiotics are desperately needed today because humankind faces unprecedented rise of bacterial infections that resist all currently available drugs [12]. Nevertheless, MmA, as a drug candidate, possesses two shortcomings. First, its pharmacokinetics is suboptimal because it gets absorbed into the bloodstream very poorly,

(C) Кужик Ю., Ребець Ю., Попко І. та ін., 2019 
making oral administration impossible. Once in the blood, the half-life of MmA there is within days range, and not few hours as for the other marketed drugs. Second, due to immensely complex chemical structure, MmA can be produced only microbiologically (e.g. via submerged fermentation). Current MmA production levels are very low (a few miligrams per liter of culture broth), necessitating the strain improvement. Although empirical approaches in the past led to isolation of several promising strains [10], their production profiles (e.g. types of moenomycins being produced) has never been studied, and these strains cannot be retrieved for further exploration. To rationalize the development of moenomycin overproducers, we have been studying the genetics of regulation of MmA biosynthesis since 2007. As a result, a number of regulators of MmA production have been discovered and put to practical purpose of increased antibiotic titers [7]. All these approaches hinged on the fact that global regulatory networks for antibiotic production are quite similar across different species. This homology-based paradigm, however, does not permit to identify genuinely novel regulators for certain metabolic pathway. One possible remedy to this problem is to use an unbiased mutagenesis protocol coupled to screening of MmA-deficient variants. Indeed, recently we demonstrated the feasibility of mariner transposon mutagenesis to find novel genes involved in modulation of the level of MmA production [11]. In this work we report the use of another transposon system, based on hyperactive Tn5 variant [9], to search for regulators of $\mathrm{MmA}$ production.

\section{Materials and Methods}

Strains and plasmids used and constructed in this work are listed in Table 1. Tryptic soy broth (Merck), oatmeal and soy-mannitol agars [3, 4] were used to grow Streptomyces and plate matings. Escherichia coli strains were grown in liquid or agar LB medium supplemented with appropriate antibiotic (if needed) at either 30 or $37^{\circ} \mathrm{C}$, respectively. For visual and microscopic lawn examination, strains were grown on aforementioned solid media. Genomic DNA from Streptomyces and plasmid DNA from E. coli were isolated using standard protocols [3]. Molecular biology enzymes were used according to recommendation of suppliers (Thermo).

Transposon mutagenesis and rescue of genomic fragments carrying Tn insertion sites in E. coli pir $^{+}$strains have been done as described in [9]. A 1.5-kb fragment carrying the fd terminator, MCS and promoterless neomycin resistance gene neo was cloned as SmaI fragment from pIJ487 [3] into pGEM T-easy vector (Promega) to give pGN1. The 515-bp fragment adjacent to moeO5 along with first $35 \mathrm{bp}$ of the ORF (moeO5p) was amplified from moeno38-5 cosmid with primers O5PFHindIII and O5RXbaI and cloned into respective sites of pGN1 to give pGNO5P. The latter was digested with NheI and MfeI and moeO5p-neo cassette was cloned into EcoRI/ XbaI sites of pOOB5 [8] to give pONO5P.. Moenomycin was extracted from $10 \mathrm{ml}$ of TSB and quantified with the help of agar plug and antibiotic disc assays as described in [6]. For cloning of all $S$. ghanaensis genes a common strategy was adopted. Briefly, all genes (along with their presumed ribosome binding sites) were amplified with dedicated primers (Table 2) to introduced $\mathrm{XbaI}$ and EcoRI recognition sites at the gene's ends. The amplicons were digested with XbaI and EcoRI and ligated to respective sites of pTES and pmoeE5script to give final constructs listed in Table 1. Sequencing of the cloned DNA fragment has been performed at the Biopolymers Facility of Harvard Medical School.

Genes that are knocked out in Tn5 S. ghanaensis mutants were analyzed using standard homology-based bioinformatics tools. Particularly, homologs were searched within GenBank database using pairwise alignment program BLASTP against taxonomy group "Streptomyces". Synteny analysis was carried out with the help of BioCyc database. Domain structure was predicted using Conserved Domain Database at NCBI. 
Ю. Кужик, Ю. Ребець, І. Попко та ін. ISSN 0206-5657. Вісник Львівського університету. Серія біологічна. 2019. Випуск 81

Table 1

Plasmids and bacterial strains used in this work

\begin{tabular}{|l|l|l|}
\hline \multicolumn{1}{|c|}{ Strain } & \multicolumn{1}{|c|}{ Relevant characteristics } & $\begin{array}{c}\text { Source/ } \\
\text { Reference }\end{array}$ \\
\hline $\begin{array}{l}\text { S. ghanaensis } \\
\text { ATCC14672 }\end{array}$ & Wild type moenomycin producer & ATCC
\end{tabular}

E. coli $\mathrm{DH} 10 \mathrm{~B} \quad$ Routine cloning host; $\mathrm{F}^{-}$mcrA $\Delta$ (mrr-hsdRMS- $\left.m c r \mathrm{BC}\right) \varphi 80$ lacZ $\Delta \mathrm{M} 15 \quad$ Invitrogen

DlacX74 recA1 end $\mathrm{A} 1$ araD139 $\Delta$ (ara, leu)7697 galU galK $\lambda \cdot$ rpsL nup $\mathrm{G}$.

E. coli ET12567 Strain for conjugative transfer of coresident plasmids; dam13::Tn9 $\left(\mathrm{Cm}^{\mathrm{r}}\right)$

pUZ8002 dcm6 hsdM hsdR zjj202::Tn10 (Tet') recF143 galK2 galT22 ara14 lacY1

xyl5 leuB6 thil tonA31 rpsL136 (Str') hisG4 tsx78 mtl1 glnV44 . pUZ8002

$-\mathrm{Km}^{\mathrm{r}}$

E. coli WM6026 lacI ${ }^{q}$ rrnB3 $\Delta$ lacZ4787 hsdR514 $\Delta$ araBAD567 $\Delta$ rhaBAD568 rph-1

att $\lambda:$ :pAE12 ( $\Delta$ oriR6K-cat::Frt5) $\Delta$ endA ::Frt

Bacillus cereus Moenomycin-sensitive test -culture

ATCC

ATCC19637

pTNM ts-orip ${ }^{\text {PSG }} a a c(3) I V\left(\mathrm{Am}^{\mathrm{r}}\right)$ hygB $\left(\mathrm{Hy}^{\mathrm{r}}\right)$; carries synthetic gene $\operatorname{tnp}(a)$ of $\operatorname{Tn} 5$

transposase; apramycin resistance gene aac(3)IV flanked with mosaic ends for $\operatorname{Tnp}(\mathrm{a})$

pONO5P $\quad \mathrm{Sp}^{\mathrm{r}} ; \varphi \mathrm{C} 31$-based vector carrying transcriptional fusion of moeO5 promoter to This work

pTES $\quad \varphi$ C31-based vector for ermEp-driven expression of cloned genes

pmoeE5script $\quad \varphi$ C31-based vector carrying moeE5p-gusA transcriptional fusion

pTESssfg_03173 pTES carrying S. ghanaensis gene ssfg_03173 under ermEp

pYK160 $\quad$ pTES carrying $S$. ghanaensis gene $s$ ffg 04363 under ermEp

pKL1j pmoeE5script where gusA was substituted with $S$. ghanaensis gene ssfg 02631; moeE5p-ssfg_02631 fusion

pTESssfg_04565 pTES carrying $S$. ghanaensis gene ssfg_04565 under ermEp

pTESssfg 05134 pTES carrying $S$. ghanaensis gene ssfg_05134 under ermEp

This work

This work

This work

This work This work

Table 2

Primers used in this study

\begin{tabular}{|lll|}
\hline \multicolumn{1}{|c}{ Name } & \multicolumn{1}{c|}{ Sequence $\left(5^{\prime} \rightarrow 3^{\prime}\right)^{*}$} & \multicolumn{1}{c|}{ Purpose } \\
\hline pMODfor & CCAACGACTACGCACTAGCCAAC & Sequencing of the \\
pTn5Oksfor & ATTCAGGCTGCGCAACTG & rescue plasmids \\
O5PFHindIII & (ATAAGCTTGTCCGGCAGGAATGCATAAC & Construction of \\
O5PRXbaI & (ATTCTAGAGTTCCGTGTGGTGGTCCAG) & pONO5P \\
ssfg_04565_XbaI_up & AAATCTAGAGTCGGCGTGAAGCTGGAGCC & Cloning of \\
ssfg_04565_EcoRI_rp & AAAGAATTCGCGGGGCGTGTTCAAGGCAG & S. ghanaensis genes \\
ssfg_05134_XbaI_up & AAATCTAGAGCACGGAGAACAGCACATGC & \\
ssfg_05134_EcoRI_rp & AAAGAATTCGATCAGGCGAGGTCACTGCC & \\
ssfg_03173_XbaI_up & AAATCTAGAATCCTCGACATCGGCCTCGAC & \\
ssfg_03173_EcoRI_rp & AAAGAATTCTACATCCGCGACACGTTCCGC & \\
160up & AAATCTAGAGTCACGACCGACTCGGTCATC \\
160rp & AAAGAATTCGTGCGCGTTACAGTCGTCCG \\
162up & AAATCTAGACACCGACTTCGGCTCGATCAC & \\
162rp & AAAGAATTCGACACGTACGGCTTGCTCATG & \\
*Restriction sites are underlined &
\end{tabular}

Results and Discussion

Transposon mutagenesis of S. ghanaensis ATCC14672. In this work we used to approaches to isolate $S$. ghanaensis Tn5 mutants with altered antibiotic activity. In a direct screening, transposon- vector pTMN was conjugally transferred into ATCC14672 and transpositions were induced and selected for as described in [9]. Single colonies were visually inspected for 
Ю. Кужик, Ю. Ребець, І. Попко та ін.

changed morphology and overlaid with $B$. cereus to check for antibiotic activity. This is rather tedious way when one has to check bioactivity of thousands of colonies. We therefore devised and tested here an alternative approach based on selection for increased resistance to kanamycin of Tn5 mutants impaired in genes for repressor(s) of moenomycin production. For this purpose, we first constructed reporter plasmid pONO5P where promoter of key MmA biosynthetic gene, moeO5, is fused to promoterless reporter gene neo for kanamycin resistance. The pONO5 $\mathrm{P}^{+} S$. ghanaensis exhibited growth on tryptic-soy agar plates supplemented with $100 \mu \mathrm{g} / \mathrm{ml}$ of kanamycin; no growth was observed at $125 \mu \mathrm{g} / \mathrm{ml}$ of kanamycin. We reasoned that transposition of Tn5 into a gene for repressor of moeO5 transcription would increase the expression of moeO5p-neo fusion. This, consequently, will enable the growth of reporter strain in presence of high concentrations of kanamycins, that would otherwise kill S. ghanaensis. Through direct screening of approximately 5000 clones we picked $21 \mathrm{Tn} 5$ mutants with altered antibiotic activity. Three mutants (TN2-29, TN12-1, TN12-7) were taken for further analysis due to notable changes in bioactivity and morphology (Fig. 1). Using pONOP5 ${ }^{+}$reporter strain we isolated about $500 \mathrm{Km}^{\mathrm{r}}$ clones of which two mutants, TN-NO12 and TN-NO17, showed increased bioactivity.
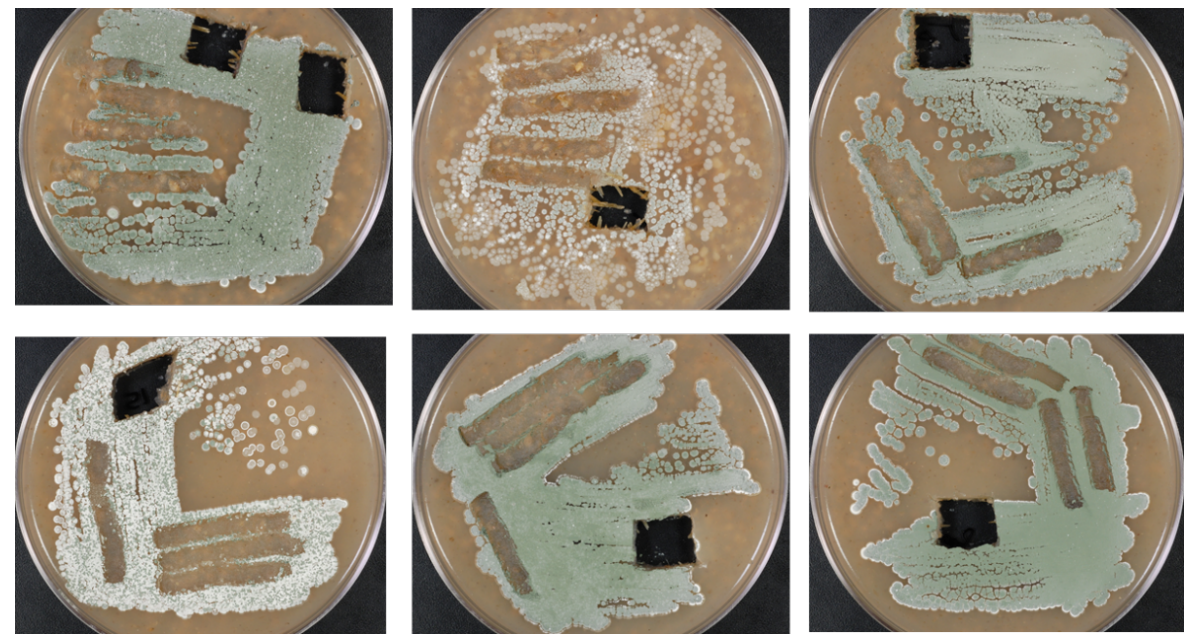

Fig. 1. 5 day-old lawns of $S$. ghanaensis strains on oatmeal agar plates. From top left corner there shown following strains: ATCC14672, TN2-29, TN12-1, TN12-7, TN-NO12, TN-NO17. Note that TN229 and TN12-7 are characterized by sparse and delayed sporulation; on second day of growth thee mutants still remain white, while the other strains are covered with dark-green spores

Identification of Tn5 insertion sites in YR mutants. Sequencing of Am ${ }^{\mathrm{r}}$ plasmid rescued from genomes of aforementioned mutants showed that in all cases resistance cassette was inserted within coding sequences of genes, proximally to presumable start codon. Information about identified insertion sites is summarized in Table 3. In TN2-29 Tn5 resides within gene ssfg_03173 for putative type III pantothenate kinase. This is essential enzyme involved in coenzyme A (CoASH) production. Indeed, high-scoring hits to Ssfg_03173 is encoded within each streptomycete genome. No ssfg_03173 paralogs can be found in S. ghanaensis genome, implying that this strain possesses alternative ways to produce $\mathrm{CoASH}$.

In TN12-1 the insertion was found within gene $s s f g \_04363$ for lipoprotein of unknown function. This protein also contains von Willebrand factor (vWF) domain. Functions of vWF domain proteins in prokaryotes remain elusive. Several genes for hypothetical proteins are situated around ssfg_04363, shedding no light onto the function of the latter. The Ssfg_04363 are 
highly conserved across Streptomyces, again pointing to its involvement in as-yet-unknown core processes.

Table 3

Tn5 insertion sites in $S$. ghanaensis YR mutants

\begin{tabular}{|llll|}
\hline Mutant & Insertion & Plausible function (BLASTP result) & Counterpart*; ID\% \\
\hline TN2-29 & ssfg_03173 & Type III pantothenate kinase; CoA synthesis & KUN23912;98 \\
TN12-1 & ssfg_04363 & YeaD2-like lipoprotein with vWF domain & WP 102928894; 96 \\
TN12-7 & ssfg_02631 & Two-component sensor histidine (His) kinase & KESOS03849;87 \\
Tn-NO12 & ssfg_04565 & BaeS-like two-component sensor His kinase & WP_040907105;96 \\
Tn-NO17 & ssfg_05134 & Class 3 adenylate cyclase & WP 051909073; 75 \\
\hline *Accession number to homologous protein sequence from validly described Streptomyces species
\end{tabular}

In the next two YR mutants, TN12-7 and TN-NO12, Tn5 derailed the expression of putative sensor histidine kinase genes ssfg_02631 and ssfg_04565, respectively. There are Ssfg_02631 and Ssfg_04565 counterpart within each streptomycete genome, pointing to their indispensability.

The gene $s s f g \_05134$ for putative adenylate cyclase in not ubiquitous in Streptomyces, suggesting that it controls less conserved, niche functions. Next to ssfg_05134 are the other genes involved in cyclic nucleotide metabolism. We noted that none of the uncovered BLAST hits for five studied ssfg genes was studied experimentally.

Moenomycin production by YR mutants under different cultivation conditions. Primary bioassays provide only rough estimation of antibacterial potency of $\mathrm{Tn}$ library, therefore we decided to revisit this issue for selected YR mutants. The latter were grown on oatmeal agar plates and cultivated in liquid TSB medium. The results of these experiments are summarized in Table 4. One can see that for TN12-1 the results of surface and submerged fermentation differ, while for the other strains the data demonstrate roughly the same range of MmA production.

Production of moenomycins by strains carrying additional copy of the genes. We cloned all aforementioned genes from ATCC14672 into actinophage phiC31 expression vectors and the resulting plasmids were introduced into ATCC14672. In this way we generated ATCC14672 derivative carrying single extra copy of a given ssfg gene. It could be expected that this extra copy might shift the moenomycin production either towards higher (if the cloned gene is for positive regulator) or lower (for repressors) level than in the ATCC14672. Results of our studies, summarized in the Table 5, demonstrate that only for ssfg_04565-expressing strain there was detected significant change in antibacterial activity as compared to control (ATCC14672) strain.

Table 4

Antibiotic activity of YR mutants

\begin{tabular}{|lccc|}
\hline \multicolumn{1}{|c}{ Strain } & Original notation* & Agar plugs,,, $\mathrm{mm}$ & Disc diffusion,,, $\mathrm{mm}$ \\
\hline ATCC14672 & - & $11 \pm 2$ & $14 \pm 2$ \\
TN2-29 (ssfg_03173) & Increase & $14 \pm 2$ & $18 \pm 1$ \\
TN12-1 (ssfg_04363) & Decrease & $13 \pm 1$ & $8 \pm 1$ \\
TN12-7 (ssfg_02631) & Decrease & $9 \pm 1$ & $16 \pm 1$ \\
TN-NO12 (ssfg_04565) & Increase & $15 \pm 2$ & $17 \pm 1$ \\
TN-NO17 (ssfg 05134) & Increase & $14 \pm 1$ & $17 \pm 1$ \\
\hline
\end{tabular}

*Strain's productivity as determined in primary bioassays, relative to production by ATCC14672

Table 5

Antibacterial activity* of recombinant ATCC14672 derivatives

\begin{tabular}{|c|c|c|}
\hline $03173^{+}$ & pYK $160^{+}$ & pTESssfg_04565 ${ }^{+}$pTESssfg_05134 \\
\hline $13 \pm 2$ & $14 \pm 1$ & $12 \pm 1$ \\
\hline
\end{tabular}

*Agar plug assay; $S$. ghanaensis was grown on TSA plates for 5 days 
In this work we report molecular genetic analysis of five Tn5 mutants of $S$. ghanaensis initially picked up for changes in antibiotic activity. For two mutants the Tn5 insertion resides in regulatory genes, for protein kinases, whose involvement in certain signaling pathways of secondary metabolism can be rather straightforwardly imagined. It is more challenging to explain how pantothenate kinase or vWF protein can be involved in moenomycin production; this will require more extensive experimental work. In this regard we note that the changes in antibiotic activity that we revealed in Tn mutants were moderate at best, and they show up only under certain conditions, such as submerged fermentation, and not growth on agar plates. The identified genes are likely not key regulators of moenomycin production, but rather modulators of certain signaling or precursor production pathways. So far, studies of mutant TN-NO12 (impaired in kinase gene ssfg_04565) showed the most consistent results. Both in solid and liquid media this mutant showed increased antibiotic activity and extra copy of this gene in ATCC14672 caused decreased antibiotic titers. The $s s f g$ _04565 gene therefore deserves more detailed experimental scrutiny. Our work also attests to the utility of reporter-based strategy for selection of mutants impaired in regulatory genes for antibiotic production.

Acknowledgements. We thank Prof. A. Luzhetskyy (Saarbrucken University, Germany) for providing pTNM plasmid for Tn5 mutagenesis. B.O. and V.F. were supported by the grants BG-80F and BG-46F, respectively, both from Ministry of Education and Science of Ukraine. V.F. and S.W. were supported by NIH grant R03TW009424. The content is solely the responsibility of the authors and does not necessarily represent the official views of the NIH. Lilia Kravciv is thanked for initial efforts in construction of $\mathrm{pKL} 1 \mathrm{j}$ plasmid.

\section{REFERENCES}

1. Gampe C. M., Tsukamoto H., Wang T. S. et al. Modular synthesis of diphospholipid oligosaccharide fragments of the bacterial cell wall and their use to study the mechanism of moenomycin and other antibiotics // Tetrahedron. 2011. Vol. 67. P. 9771-9778.

2. Herrmann S., Siegl T., Luzhetska M. et al. Site-specific recombination strategies for engineering actinomycete genomes // Appl. Environ. Microbiol. 2012. Vol. 78. P. 1804-1812.

3. Kieser T., Bibb M.., Buttner M. et al. Practical Streptomyces genetics. Norwich: John Innes Foundation. 2000. 634 p.

4. Koshla O., Lopatniuk M., Rokytskyy I. et al. Properties of Streptomyces albus J1074 mutant deficient in tRNA(Leu)(UAA) gene bldA // Arch. Microbiol. 2017. Vol. 199. P. 1175-83.

5. Luo Y., Huang H., Liang J. et al. Activation and characterization of a cryptic polycyclic tetramate macrolactam biosynthetic gene cluster // Nat. Commun. 2013. Vol. 4. P. 2894-2909.

6. Makitrynskyy R., Rebets Y., Ostash B. et al. Genetic factors that influence moenomycin production in streptomycetes // J. Ind. Microbiol. Biotechnol. 2010. Vol. 37. P. 559-566.

7. Makitrynskyy R., Ostash B., Tsypik O. et al. Pleiotropic regulatory genes bldA, adpA and absB are implicated in production of phosphoglycolipid antibiotic moenomycin // Open Biology. 2013. Vol. 3. 130121.

8. Ostash B., Doud E. H., Lin C. et al. Complete characterization of the seventeen step moenomycin biosynthetic pathway // Biochemistry. 2009. Vol. 48. P. 8830-8841.

9. Petzke L., Luzhetskyy A. In vivo Tn5-based transposon mutagenesis of Streptomycetes // Appl. Microbiol. Biotechnol. 2009. Vol. 83. P. 979-986.

10. Schuricht U., Endler K., Hennig L. et al. Studies on the biosynthesis oft he antibiotic moenomycin A // J. Prakt. Chem. 2000. Vol. 342. P. 761-769. 
Ю. Кужик, Ю. Ребець, І. Попко та ін. ISSN 0206-5657. Вісник Львівського університету. Серія біологічна. 2019. Випуск 81

11. Sehin Y., Koshla O., Dacyuk Y. et al. Gene ssfg_01967 (miaB) for tRNA modification influences morphogenesis and moenomycin biosynthesis in Streptomyces ghanaensis ATCC14672 // Microbiology. 2019. Vol. 165. P. 233-245.

12. Wright G.D. Q\&A: antibiotic resistance: what more do we know and what more can we do? // BMC Biol. 2013. Vol. 11. P. 51. doi: 10.1186/1741-7007-11-51.

Стаття надійшла до редакиії 04.09.19

прийнята до друку 14.11.19

\title{
ТРАНСПОЗОННИЙ МУТАГЕНЕЗ STREPTOMYCES GHANAENSIS ATCC14672 НА ОСНОВІ TN5: ПОШУК НОВИХ РЕГУЛЯТОРІВ ПРОДУКЦІї МОЕНОМІЦИНУ
}

\section{Ю. Кужик ${ }^{1}$, Ю. Ребець ${ }^{2}$, І. Попко ${ }^{1}$, I. Осташ ${ }^{1}$, С. Уокер ${ }^{2}$, В. Федоренко ${ }^{1}$, Б. Осташ ${ }^{1, *}$}

\author{
${ }^{1}$ Львівський національний університет імені Івана Франка \\ вул. Грушевського, 4, Львів 79005, Україна \\ ${ }^{2}$ Гарвардська медична школа \\ кільие Блекфена, 4, Бостон, МА 02115, США \\ e-mail: bohdan.ostash@lnu.edu.ua
}

\begin{abstract}
Streptomyces ghanaensis ATCC14672 - один із генетично охарактеризованих природних продуцентів моеноміцину А (MmA), унікального фосфогліколіпідного антибіотика, що може прямо інгібувати пептидогліканові глікозилтрансферази. Наразі на ринку немає ліків, які би діяли за таким механізмом. Існує значний інтерес у розробці ліків на основі МmА для лікування множинно стійких грампозитивних інфекцій. Відповідно, неабиякий інтерес становить розробка мікробіологічних підходів до глибинного культивування штаму-продуцента цієї природної сполуки. Наявні штами ATCC14672 накопичують мізерні кількості MmA, що протягом останнього десятиріччя стимулює дослідження генетичного контролю його біосинтезу. Наше розуміння регуляції продукції MmA наразі головно грунтується на порівнянні за гомологією. Тобто гомологи відомих плейотропних регуляторів продукції антибіотиків виявляли у геномі АТCC14672 і далі характеризували експериментальними методами. Хоча такий підхід загалом був успішний, за його межами залишилися ті регулятори продукції $\mathrm{MmA}$, що не гомологічні з регуляторами, описаними для модельних стрептоміцетів. У цій статті ми описуємо спробу виявити нові гени, задіяні у регуляції біосинтезу моеноміцину, за допомогою кодон-оптимізованого транспозона Tn5, що репрезентує об'єктивний спосіб виявлення справді нових регуляторів. У результаті первинного скринінгу транспозонної бібліотеки нам вдалося ідентифікувати п'ять Tn5 мутантів, що відрізнялися за морфологією та/або сумарною антибіотичною активністю. Методом секвенування ДНК ідентифіковано сайти інсерції Tn5 у геномах мутантів і повторно проаналізовано їхні рівні продукції моеноміцину. Це привело до виявлення двох мутантів зі збільшеною продукцією антибіотика. Виявлені гени клоновано у вектори експресії та введено у штам дикого типу (АТСС14672) для вивчення впливу додаткової копії гена на штам. Один із генів, ssfg_04565, справляв негативний вплив на антибіотичну активність, коли його ввели у штам АТСС14672 на плазміді. Імовірні функції генів обговорено у контексті розуміння регуляції вторинного метаболізму.
\end{abstract}

Ключові слова: Streptomyces ghanaensis, Tn5, транспозонний мутагенез, регуляторні гени 